\title{
Contextualizing Salafism
}

By Mark Sedgwick, Associate Professor, PhD, Department of the Study of Religion, Aarhus University

The importance of Salafism, both in the Muslim world and in Europe, has been quickly grasped by scholars and by governments, and some excellent studies of Salafism in individual countries have been published. Methodological and analytical problems, however, remain. One problem is defining the topic: what is and what is not Salafi? Classification is not assisted by internal divisions within the Salafi movement that result in disagreement among Salafis themselves as to who and what is and is not Salafi, nor by the way in which Salafis do not always describe themselves as Salafi, often preferring ahl al-sunna wa'l-jama'a, sometimes shortened to plain "Sunni," terms which could, of course, describe almost any non-Shi'i Muslim. A related problem is that the term "Salafi" is sometimes applied by outsiders with little justification, often in the press, but also by authorities such as Hillel Fradkin, director of the Center for Islam, Democracy and the Future of the Muslim World at the Hudson Institute, a "conservative" American think tank, who classified the Muslim Brotherhood as Salafi, on the basis that they were part of "the worldwide Islamic phenomenon and movement variously known as Islamism, Salafism, radical Islam, militant Islam, political Islam and the like.,

The difficulties that apply to the study of Salafism in the Muslim world are compounded when it comes to the study of Salafism in Europe by the political sensitivity of the topic, and the interest that security agencies have in it. In a public document, the Dutch internal security service, the AIVD, has identified Salafism of all varieties as a significant national security threat and proposed strategies to counter its spread. ${ }^{\text {ii }}$ While I do not know of any other European government authority that has taken such a clear public stand against Salafism, the basic trend is similar across Western Europe, and it is to be expected that some Salafis will be reluctant to talk to researchers, or will actively seek to mislead them.

Under these circumstances, it is useful to go behind the "Salafi" label. One useful approach is to look at the texts and scholars that are referred to, but this approach risks

(C) Forfatteren og Tidsskrift for Islamforskning, ISSN 1901-9580, publiceret 15-03-2010 
missing aspects of Salafism as a social movement as well as an intellectual movement, and as a practice as well as a theology. Contextualization thus becomes especially important, and will be briefly discussed in this essay.

At present, two very popular analyses are what may be called the socio-cultural and the security-political. The socio-cultural analysis understands Salafism in terms such as postIslamism: the failure of political Islam has opened a space that has been occupied by a form of Islam that shares some characteristics with the political Islam it has replaced, and also responds to the circumstances of socially marginalized or even excluded Muslim minorities. ${ }^{\text {iii }}$ The security-political school of analysis follows Quintin Wiktorowicz's distinction between Purists, Politicos, and Jihadis: purists are not interested in politics, Politicos are but do not favor jihad, and Jihadis do favor jihad. ${ }^{\text {iv }}$

Both these analyses have their virtues. The socio-cultural analysis, for example, reveals how Salafism is in some ways a culture of protest and dissent." The security-political analysis highlights questions, which are important for Salafis themselves, and also of real public concern. Both analyses, however, emphasize contemporary conditions: modernity, and the confrontation between sections of the Muslim world and sections of the West. Salafism, however, is also an instance of a form of Islam that has been found periodically throughout Islamic history. As Ernest Gellner (1925-1995) wrote in 1981,

Within Muslim societies, there is a permanent, if sometimes latent, tension and opposition between two styles of religious life. On the one hand, there is a puritanical, individualist, scripturalist ideal of a single deity ... This version spurns mediation, and neither requires not formally allows clergy: it presupposes only a literate class of scribes who act as guardians and exegetes of the revelation . . . In contrast to this vision, there is the 'associationist' ideal . . . which allows mediation, propitiation, ritual and devotional excess, and religious hierarchy. ${ }^{\mathrm{vi}}$

Salafism is clearly an instance of the puritanical, individualist and scripturalist, and certainly spurns mediation. As an instance of a form of Islam that has been found periodically throughout Islamic history, then, it should also be understood as a response to factors deeper than the contemporary ones which the currently popular socio-cultural and security-political analyses reveal. 


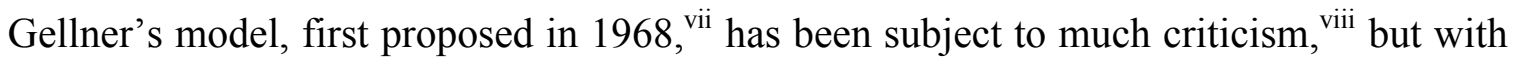
some modification can still serve as a useful basis for analysis. The first necessary modification is to reorganize the characteristics of the two styles of religious life in Islam. The eighteenth century, for example, was notable for movements that combined scripturalism with mediation and ritual: those described by scholars as "neo-Sufism" and associated with the tariqa Muhammadiyya movement, led by scholar-Sufis such as Ahmad al-Tijani and Ahmad ibn Idris. ${ }^{\text {ix }}$ There is an interesting relationship between these movements and that led by Muhammad ibn Abd al-Wahhab, the main origin of today's Salafism, though the precise nature of the relationship remains unclear, given that so much work on the seventeenth and eighteenth centuries remains to be done. What is clear is that all these movements stood against much the same thing: what they saw as excess, and the religious hierarchy of the time. On the one hand, then, there is puritanical scripturalism, and on the other hand there is perceived excess and religious hierarchy.

The second necessary modification is to recognize that scripturalism is not so much about unmediated readings of original texts as it is about authority. Gellner took scripturalism at face value, as reliance on the Quran and hadith. In fact, entirely unmediated reading of any text is impossible, since every act of reading is an act of interpretation, and since every act of interpretation is a function of the interpreter's circumstances and agenda. This is especially true when it comes to hadith material, given the multiplicity of possible readings. Scripturalists may claim that the meanings they find in their texts are plainly there, but if this were truly the case, there would be no need to point them out.

Scripturalism is not so much about content as about authority. Generally accepted understandings normally have the authority of tradition and precedent, and certainly of consensus, ijma '-whether this is understood in its classic sense in usul al-fiqh or in a looser sense. Tradition is one of three possible basic sources of authority, as Max Weber (18641920) recognized. Anyone who wishes to challenge a generally accepted understanding or practice, then, needs some other, higher, authority. Where faith in divine revelation remains intact, Weber's rational-legal authority is powerless to challenge it, and the only 
alternative is the authority of God - Weber's charismatic authority. This alternative authority may come in two forms: indirect, through sacred texts, or direct. Direct divine authority is a function of non-scriptural contact with the divine. This may take two forms, only one of which is acceptable in Islam. It is possible to claim a new divine revelation, as the modernist Indian Ghulam Ahmad did, but this claim places the claimant outside most Muslims' understandings of Islam. The other, acceptable form of direct divine authority is divine inspiration of the type commonly associated with Sufi revivalists such as Abd al-Aziz al-Dabbagh, ${ }^{\mathrm{x}}$ and to a lesser extent with Ahmad al-Tijani and Ahmad ibn Idris. Indirect divine authority may be derived from contact with the divine through sacred texts, and was claimed by Muhammad ibn Abd al-Wahhab, as well as by today's Salafis. Scripturalism, then, is a form of authority, and does not in fact exclude the intermediation of the presiding scripturalist. Scripturalists may maintain that the scriptures can be understood in and of themselves, but they are in practice invariably proposing a new interpretation of their own.

The third necessary modification to Gellner's model is to explain the relationship between scripturalism and puritanism. Gellner seems to have assumed that scriptural Islam was "true" Islam, and "true" Islam was puritan, ${ }^{\mathrm{xi}}$ in the sense of being highly restrictive. It is often possible, however, to support both restrictive and permissive interpretations from the same basic texts, the Quran and hadith. The discussion over the permissibility of music, for example, is almost as old as Islam itself, and a variety of views are possible on a scriptural basis. ${ }^{\text {xii }}$ In practice, scripturalists invariably tend toward the most restrictive possible interpretations. Muslim society, in contrast, has often tended toward more permissive interpretations. This essay does not provide space for a full investigation of this question, but it is possible that the tendency of society towards permissive interpretations is one cause of scripturalism's puritanism: because scripturalists are challenging consensus, they challenge the standard interpretations of that consensus, whatever they are. If the consensus ever represented a restrictive interpretation, one might find scripturalists being permissive. 
The two basic styles of religious life in Islam, then, are consensus-based hierarchical ritualism and periodic challenges to this that are puritan and derive their authority from scripturalism or divine inspiration, or perhaps from a mixture of the two. Seen in this way, Islam may be more like other religions than Gellner supposed, except perhaps in the frequency of these challenges, which are conceived of by some Muslims in terms of tajdid (renewal), referring to the famous hadith first reported by the ninth-century scholar Abu Da'ud, whose Sunan opens with the promise that "God will send to this umma at the start of every century someone who will renew (yujaddid) religion."xiii This hadith establishes an expectation of a cyclical model of decline and renewal that is a more optimistic alternative to the model of the development of a multiplicity of firqat (sects) of which only one will be saved, the model favored by contemporary Salafis. Even so, at one point the list of mujaddidun (renewers) on Wikipedia briefly included both Ibn Abd al-Wahhab and the great Salafi scholar Muhammad Nasir al-Din al-Albani. ${ }^{\text {xiv }}$

There is no agreement among scholars as to what causes these periodic renewals or challenges to consensus. Gellner himself followed Ibn Khaldun's (1332-1406) model, according to which tough nomadic tribes periodically take over decadent towns, then become urbanized and decadent themselves, and are in their turn taken over by fresh waves of nomads, who have (in Gellner's addition to Ibn Khaldun) sometimes previously been won over to puritan scriptural Islam. ${ }^{\mathrm{xv}}$ Gellner's explanation might be loosely identified with the politico-security analysis of Salafism. Ira M. Lapidus has argued that puritan scriptural challenges are a response to dislocation and crisis, and explains both eighteenth-century revivalism and that of the late twentieth century in terms of the consequences of Western economic penetration of the Arab world. ${ }^{\text {xvi }}$ This explanation might be loosely identified with the socio-cultural analysis of contemporary Salafism. A third explanation might be constructed on the basis of denominalization theory: the idea that a sect that does not fail and vanish may become a denomination, and that the commitment of participants in a denominationalized system will decline over time. The way is then open for a new sect to challenge the consensus. ${ }^{\text {xvii }}$ 
The major weakness in Lapidus's argument, as Lapdidus himself almost recognizes, ${ }^{\text {xviii }}$ is that the link between Western expansion and many of the greatest revivalists of the eighteenth century is weak. The West is never once referred to by Abd al-Aziz al-Dabbagh, Muhammad ibn Abd al-Wahhab, Ahmad al-Tijani or Ahmad ibn Idris, none of whom ever met a Westerner. That these revivalists were frequently located on the Islamic periphery-Nejd, the Hijaz, Yemen and the Sahara are all important-is an argument in favor of Gellner's explanation, and is also compatible with denominalization theory: denominations are best established at the center, and so may be most easily challenged on or from the periphery. ${ }^{\text {xix }}$ Ibn Khaldun's model of toughness decreasing over time is also compatible with denominalization theory's model of commitment decreasing over time.

Contemporary Salafism, then, may be understood as the latest of many periodic challenges to established, consensus-based, hierarchical ritualism, as well as in terms of response to contemporary conditions. Like many other such challenges, it originates on the periphery: Saudi Arabia, where the earlier challenge of Ibn Abd al-Wahhab had become denominationalized, but where the established consensus of other parts of the Muslim world was still absent. If it is doing especially well in Western Europe, that may be partly because Western Europe is in effect the Islamic periphery, an area where the general Islamic consensus was and is only weakly established. Like other such challenges, Salafism may be expected to become denominationalized and thus, with time, more moderate.

The model proposed by this essay will be of little use for the researcher faced with a European Salafi who claims not to be a Salafi. It provides, however, an example of what may be achieved by alternative contextualizations of Salafism, within the broader context of Islam as a whole.

${ }^{i}$ Hillel Fradkin, "The History and Unwritten Future of Salafism," Hudson Institute paper, 2008, p. 5. Available http://www.hudson.org/index.cfm?fuseaction=publication_details\&id=5509. Accessed August 11, 2009.

ii AIVD, "The radical dawa in transition: The rise of Islamic neoradicalism in the Netherlands" (2007), pp. 9-10, 59-60, 73-77. Available https://www.aivd.nl/contents/pages/90126/theradicaldawaintransition.pdf. Accessed January 23, 2009.

iiiisee, for example, International Crisis Group, "La France face à ses musulmans: Émeutes, jihadisme et dépolitisation," report no. 72 (March 9, 2006), pp. 13-17.

(C) Forfatteren og Tidsskrift for Islamforskning, ISSN 1901-9580, publiceret 15-03-2010 
${ }^{\text {iv }}$ Quintan Wiktorowicz, “Anatomy of the Salafi Movement,” Studies in Conflict \& Terrorism 29 (2006), pp. 207-239.

${ }^{\mathrm{v}}$ Anyone who doubts this should consider the remarkable banner of one popular English-language Salafi website, forums.islamicawakening.com.

${ }^{\mathrm{vi}}$ Ernest Gellner, Muslim Society (Cambridge: Cambridge University Press, 1981), p. 159.

vii Ernest Gellner, “A Pendulum Swing Theory of Islam,” Annales de Sociologie Marocaines, 1968, pp. 514, reprinted in Roland Robertson (ed), Sociology of Religion: Selected Readings (Harmondsworth: Penguin, 1969), pp. 127-40.

viii H. Munson, "Rethinking Gellner's segmentary analysis of Morocco's Ait 'Atta," Man 28 (1993), pp. 26780. Also Mark Sedgwick, "Scripturalist and Sufi Revival in Late Pre-Modern Islam," unpublished paper delivered at the annual meeting of the Middle East Studies Association, San Francisco, November 20-23, 2004. Some sections of this essay are drawn from that paper.

${ }^{i x}$ One classic account remains Sean O'Fahey, Enigmatic Saint: Ahmad Ibn Idris and the Idrisi Tradition (Evanston: Northwestern University Press, 1990). See also Bernd Radtke, "Sufism in the 18th Century: An Attempt at a Provisional Appraisal," Die Welt des Islams 36 (1996), pp. 326-364. For an attempt to pull together later research, see Mark Sedgwick, Saints and Sons: The Making and Remaking of the Rashidi Ahmadi Sufi Order, 1799-2000 (Leiden: Brill, 2005), pp. 27-65.

${ }^{\mathrm{x}}$ The teachings of Abd al-Aziz al-Dabbagh (1689-1720), a Sufi shaykh in Morocco, were spread through the account of his life and teachings by a Moroccan 'alim, Ahmad al-Lamati (1679-1743), author of Kitab al-dahab al-ibrīz min kalām sayyid̄̄ 'Abd al-Azīz al-Dabbāgh, 'the Ibriz' for short. The Ibriz was one of the most widely distributed and then printed texts of the time; references are to be found to it in later Sufi works from across the Arab world.

${ }^{\mathrm{xi}}$ Gellner, Muslim Society, p. 54.

xii This is one of the things that have kept the discussion going.

xiii Abu Da'ud, Sunan, quoted in Ella Landau-Tasseron's interesting article, “The 'Cyclical Reform:' A Study of the mujaddid Tradition," Studia Islamica 70 (1989), p. 79.

xiv“"Mujaddid," Wikipedia, December 2006 and September 2007. http://en.wikipedia.org/wiki/Mujaddid. This page sees many edits as its list is contested by partisans of various schools and scholars.

${ }^{\mathrm{xv}}$ Gellner, "Pendulum Swing," pp. 136-38.

${ }^{x v i}$ Ira M. Lapidus, "Islamic Revival and Modernity: The Contemporary Movements and the Historical Paradigms," Journal of the Economic and Social History of the Orient 40 (1997), pp. 444-460.

${ }^{x v i i}$ For a discussion of denominationalization in Islam, see Mark Sedgwick, "Establishments and Sects in the Islamic World," in Phillip Lucas and Thomas Robbins (eds), New Religious Movements in the 21st Century: Legal, Political, and Social Challenges in Global Perspective (New York: Routledge, 2004), pp. 283-312.

xviii Lapidus, "Islamic Revival and Modernity," pp. 456-57.

${ }^{x i x}$ An interesting parallel is the American frontier, notably the "burned-over district" in Upstate New York, which saw an extraordinary number of religious revivals during the nineteenth century.

(C) Forfatteren og Tidsskrift for Islamforskning, ISSN 1901-9580, publiceret 15-03-2010 